\title{
Foreign body in the stomach: Dentures
}

\author{
İsmail Zihni', Oktay Karaköse' ${ }^{1}$ Kazım Çağlar Özçelik', Hüseyin Pülat ${ }^{1}$, Ali Duran²
}

ABSTRACT $\begin{aligned} & \text { Although it is mostly observed in childhood, swallowing foreign bodies causes morbidity and mortality of a high } \\ & \text { percentage in the adult age group. Swallowed foreign bodies can be both harmless as well as life-threatening. The } \\ & \text { number, shape, size, and time of the swallowed foreign body to get deposited in the specific location determines the } \\ & \text { type of treatment. Late diagnosis and treatment is an important problem that causes perforation and obstruction. In } \\ & \text { this article, we presented a 39-year-old male patient who swallowed his denture while sleeping. } \\ & \text { Keywords: Surgery, stomach, foreign body, endoscopy }\end{aligned}$

\section{INTRODUCTION}

The treatment approach to a swallowed foreign body depends on the size, number, time from swallowing to its deposition in the specific location, and whether the edges are sharp or smooth (1). They are mostly lodged in the esophagus and then the stomach. While most swallowed foreign bodies are removed spontaneously without any need for surgery, some cases are occasionally encountered that require surgical intervention (2). The approaches to be applied are endoscopy, observation, and surgery. For patients presenting in the early stage with the foreign body in the stomach, it can be removed endoscopically in a majority of cases. In delayed cases or those where endoscopic removal cannot be applied, conservative observation is then applied (3). When there is even one complication such as perforation, bleeding, or mechanical intestinal obstruction, a surgical approach is inevitable. In this paper, a patient is presented who swallowed a prosthetic tooth and required surgery.

\section{CASE PRESENTATION}

A 39-year-old male patient presented at the Department of Emergency after having swallowed a prosthetic tooth while sleeping. His vital signs were stable. In the physical examination, pulmonary sounds were normal and the intestinal sounds were normo-active. In the abdominal examination, tenderness, defense, or rebound were not determined. The laboratory values were within normal limits. On the pulmonary radiograph, no free air was determined in the mediastinum. On the upright direct abdominal radiograph, the prosthetic tooth was observed as a metal body with opacity (Figure 1). Endoscopy was applied to the patient. The prosthetic tooth was observed in the stomach and was removed as far as the proximal esophagus with endoscopy (Figure 2). The sharp metal parts of the tooth were lodged in the cricopharyngeal narrowness. Because there was a risk of perforation, the procedure was terminated and the tooth was left in the stomach. It was decided to apply laparotomy to prevent the development of any complication. With gastrotomy, the prosthetic tooth of $5 \times 4 \mathrm{~cm}$ with sharp metal notches, together with a part of the gum where it was implanted, was removed (Figure 3). No complications developed in the postoperative period and the patient was discharged on the fifth day.

Cite this paper as: Zihni I, Karaköse 0, Özçelik KÇ, Pülat $\mathrm{H}$, Duran A. Foreign body in the stomach: Dentures. Turk J Surg 2017; 33: 222-223.

'Division of Surgical Oncology, Süleyman Demirel University School of Medicine, Isparta, Turkey

${ }^{2}$ Clinic of General Surgery, KIzltepe State Hospital, Mardin, Turkey

Address for Correspondence Oktay Karaköse e-mail: oktaykarakose@gmail.com

Received:08.01.2015

Accepted: 16.01.2015

Available Online Date: 06.07.2015

@) Copyright 2017

by Turkish Surgical Association

\section{DISCUSSION}

The swallowing of a foreign body is a frequent reason for presentation at the emergency department. Although it is less common in adults than children, it is often encountered in those with mental retardation, psychiatric disorders, and drug addiction and in prisoners (4). The foreign bodies swallowed are different according to the age group. In children, they are primarily coins, toys, and pens. In adults, meat, fish, and meat bones; pins; and teeth are the most common foreign bodies. In those with psychiatric disorders and prisoners, belts, razor blades, knives, and stones are the foreign bodies that have been reported to be swallowed (5).

There are three main treatment pathways: endoscopy, observation, and surgery. The majority of foreign bodies are spontaneously passed out of the body with feces without any complications. Studies in the literature have reported spontaneous removal of $75.6 \%$ of the foreign bodies, endoscopic removal in $19 \%$, and by a surgical approach in $4.8 \%(6)$.

When the patient presents early symptoms and the swallowed foreign body is proven to be in the stomach, endoscopy should be attempted first. If endoscopy is not possible and the foreign body is small or 


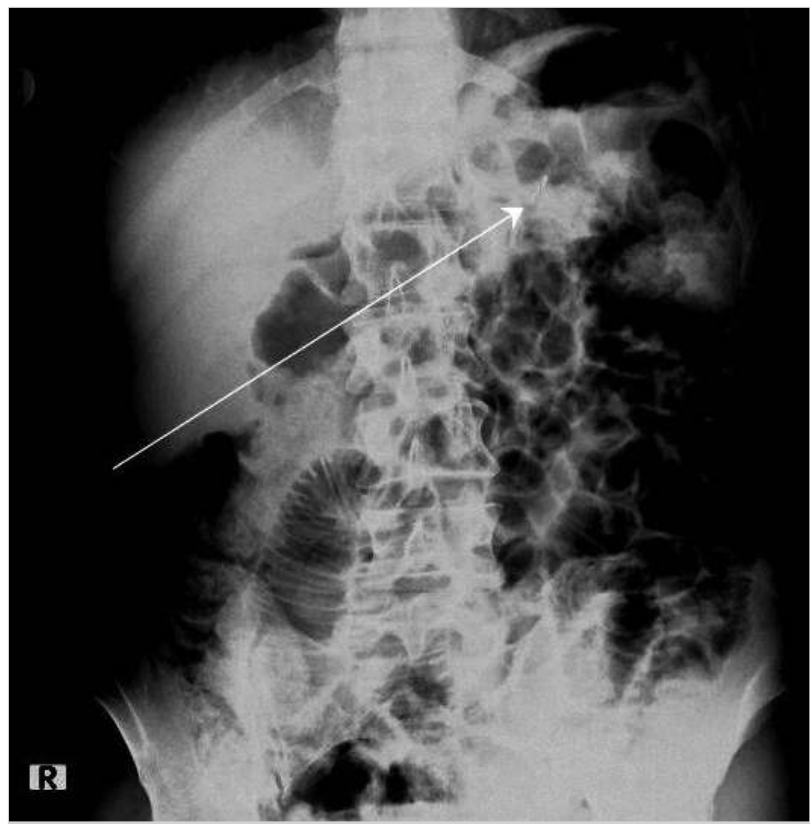

Figure 1. The prosthetic tooth observed as a metal body with opacity on the upright direct abdominal radiograph

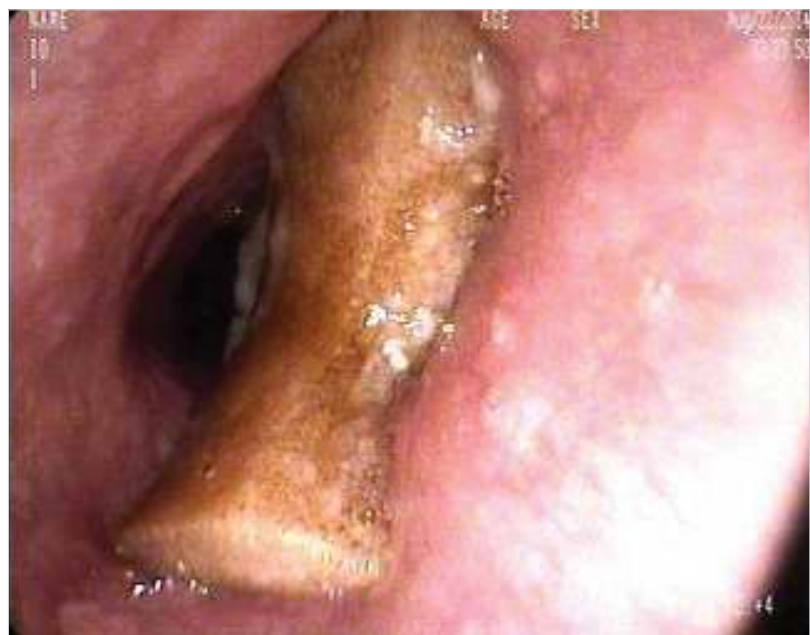

Figure 2. The prosthetic tooth in the proximal esophagus

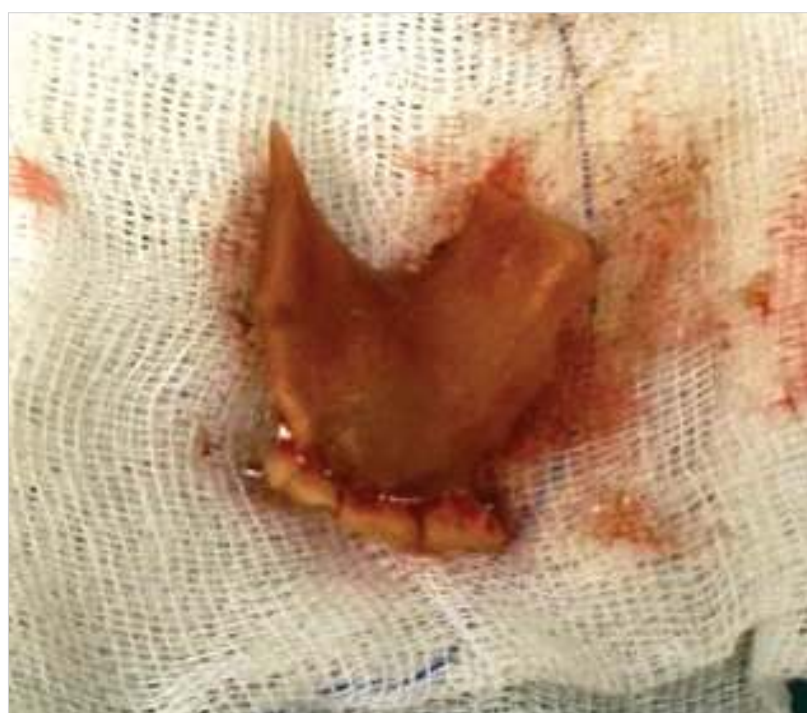

Figure 3. The prosthetic tooth together with palate tissue where it was implanted has passed into the small intestine, the patient should be kept under observation (7). When there is no movement of sharp or pointed objects ( $4 \mathrm{~cm}$ in length and $2 \mathrm{~cm}$ in diameter) for 3 days and of blunt objects for more than 7 days in the gastric or duodenal region, removal by endoscopic or surgical means is required (8). In the current case, endoscopy was initially attempted, but because of the risk of perforation, surgical intervention was required.

\section{CONCLUSION}

In the early stages, foreign bodies in the stomach and esophagus can be removed by endoscopy. Because of the low morbidity and mortality and ease of the procedure, endoscopy continues to be the most reliable method. However, foreign bodies that cannot be removed by endoscopy or that create a risk of complications must be removed by a surgical procedure.

Informed Consent: Written informed consent was obtained from patient who participated in this case.

\section{Peer-review: Externally peer-reviewed.}

Author Contributions: Concept - I.Z., O.K., K.Ç.Ö.; Design - I.Z., K.Ç.Ö., H.P.; Supervision - I.Z., O.K., H.P., A.D.; Materials - O.K., H.P., A.D.; Data Collection and/or Processing - I.Z., K.Ç.Ö., H.P.; Analysis and/or Interpretation - I.Z., K.Ç.Ö.; Literature Review - O.K., H.P., A.D.; Writer - I.Z.; Critical Review - H.P., A.D.

Conflict of Interest: No conflict of interest was declared by the authors.

Financial Disclosure: The authors declared that this study has received no financial support.

\section{REFERENCES}

1. Rajagopal A, Martin J, Matthai J. Ingested needles in a 3-monthold infant. J Ped Surg 2001; 36: 1450-1451. [CrossRef]

2. Kim SS, Kim Jl, Kim SW, Kim SW, Yang YS, Cho SH, et al. Management of foreign bodies in the gastrointestinal tract: an analysis of 104 cases in children. Endoscopy 1999; 31: 302-304. [CrossRef]

3. Ikenberry SO, Jue TL, Anderson MA, Appalaneni V, Banerjee S, Ben-Menachem T, et al. Management of ingested foreign bodies and food impactions. Gastrointest Endosc 2011; 73: 10851091. [CrossRef]

4. Başpınar İ, Şahin S, Erdoğan G. Acute mechanical intestinal obstruction after ingestion of foreign bodies: a case report. Ulus Travma Acil Cerrahi Derg 2010; 16: 92-94.

5. Sayır F, Çobanoğlu U, Sertoğullarından B. Interestingly foreign bodies in esophageal and bronchial system: analysis of 9 cases. J Clin Anal Med 2012; 3: 278-282.

6. Velitchkov NG, Grigorov GI, Losanoff JE, Kjossev KT. Ingested foreign bodies of the gastrointestinal tract: retrospective analysis of 542 cases. World J Surg 1996; 20: 1001-1005. [CrossRef]

7. Park JH, Park CH, Park JH, Lee SJ, Lee WS, Joo YE, et al. Review of 209 cases of foreign bodies in the upper gastrointestinal tract and clinical factors for successful endoscopic removal. Korean J Gastroenterol 2004; 43: 226-233.

8. Tokar B, Çevik AA, Illhan H. Ingested gastrointestinal foreign bodies: predisposing factors for complications in children having surgical or endoscopic removal. Ped Surg Int 2007; 23: 135-139. [CrossRef] 